International Journal of

Supply Chain

Management

(IJSCM)

INFLUENCE OF LOGISTICS OPTIMIZATION ON PERFORMANCE OF FREIGHT FORWARDING COMPANIES

IN KENYA

Raphael Kiluu Muoki and Dr. Makori Moronge

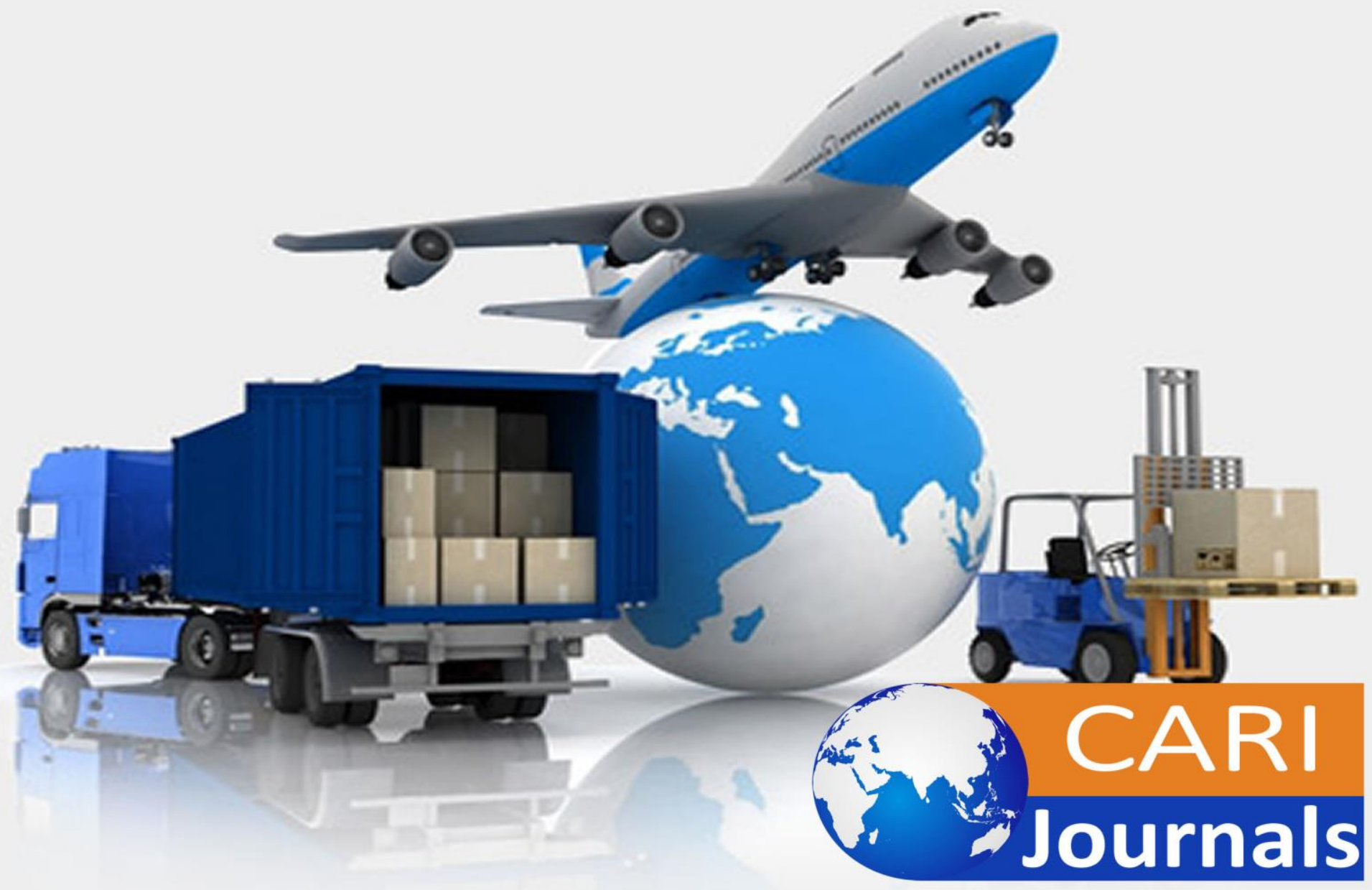




\title{
Influence of Logistics Optimization on Performance of Freight Forwarding Companies in Kenya
}

\author{
${ }^{1 *}$ Raphael Muoki Kiluu \\ ${ }^{1}$ Post Graduate Student: Department of Procurement and Logistics \\ Jomo Kenyatta University of Agriculture and Technology \\ *Corresponding Author's E-mail: kiluumuoki@ gmail.com \\ ${ }^{2 *}$ Dr. Makori Moronge \\ Lecturer, Department of Procurement and Logistics, \\ *Jomo Kenyatta University of Agriculture and Technology
}

\begin{abstract}
Purpose: The purpose of the study is to investigate the influence of logistics optimization on performance of freight forwarding companies in Kenya.

Methodology: Descriptive research design was adopted. The study preferred this method because it allows an in-depth study of the subject. Data was collected from deputy heads and heads of procurement in 45 freight forwarding companies in Kenya, who are registered members of KIFWA according to its 2019 directory. Questionnaires were used to collect data. The questionnaires were tested for validity and reliability using $10 \%$ of the total sample respondents. Data was analyzed through descriptive statistical methods such as means, standard deviation, frequencies and percentage. Inferential analyses were used in relation to correlation analysis and regression analysis to test the relationship between the four explanatory variables and the explained variable. Multiple regression models were used to show the relationship between the predicted variable and the predictor variables.
\end{abstract}

Results and conclusion: The independent variables reported $\mathrm{R}$ value of 0.846 indicating that there is perfect relationship between dependent variable and independent variables. $\mathrm{R}$ square value of 0.716 which means that $71.6 \%$ of the corresponding variation in performance of the freight forwarding companies can be explained or predicted by (logistics information system, freight management, distributor base rationalization and transport planning) which indicated that the model fitted the study data. The findings of the study indicated that logistics information system, freight management, distributor base rationalization and transport planning have a positive relationship with performance of freight forwarding companies in Kenya.

Unique contribution to theory, policy and practice: the study recommended that freight forwarding companies should embrace logistics optimization so as to improve performance and further researches should to be carried out in other institutions to find out if the same results can be obtained. 
International Journal of Supply Chain and Logistics

ISSN 2520-3983 (Online)

Vol. 5, Issue No.1, pp 46 - 66, 2021

$\underline{\text { www.carijournals.org }}$

Keywords: Logistics information system, freight management, distributor base rationalization and transport planning.

\subsection{INTRODUCTION}

The competitive freight forwarding environment is one that is rapidly changing as globalization and technology force organizations to constantly seek ongoing improvement in all areas in terms of their knowledge, flexibility and performance (Lau \& Zhang, 2016). Logistics, for example, is receiving growing attention as an area in which efficiency and productivity increases can be made in order to improve customer service and to lower costs (Sahay \& Mohan, 2016). In order to compete successfully in the dynamic freight forwarding environment, organizations are increasingly choosing to focus on their own area of competence and expertise (Kersten, Bemeleit \& Blecker, 2016). Supply chains have grown more global and interconnected; as a result, they have increased their exposure to shocks and increased the frequency of disruptions. Supply chain speed only exacerbates the problem. Even minor missteps and miscalculations can have major consequences as their impacts spread throughout complex supply chain networks (Woods, 2014). As compliance mandates, suppliers and information flows multiply, supply chains are becoming more complex, costly and vulnerable. Organizations are finding it increasingly difficult to respond to these challenges, especially with conventional supply chain strategies and designs.

Freight forwarding industry being a multimillion industry, the capital is quite an intensive investment, with a very complex supply chain which has grown more global and interconnected; as a result, they have increased their exposure to shocks and increased the frequency of disruptions. Supply chain speed only exacerbates the problem. Even minor missteps and miscalculations can have major consequences as their impacts spread like viruses throughout complex supply chain networks (Togar, Alan \& Wright, 2015). An organisation will always face challenges in responding to challenges, especially with conventional supply chain strategies and designs, since most of the organisation have viewed themselves as entities that exist independently from others and indeed need to compete in order to survive, there is almost tendency to operate exclusive in driving much of corporate strategy, However, such philosophy can be self-defeating if it leads to unwilling to cooperate in order to complete, behind this seemingly paradoxical concept is the idea of supply chain integration and management (Sunil \& Meindl, 2014).

According to Rajendra (2011) in a study done focusing on the freight forwarding sector, the inventory handling systems were not up to date and could not be classified as $70 \%$ reliable thus impacting negatively on the distribution to the final consumer. Unreliability in the supply chain management system used by manufactures was found to be literally expensive and impacted poorly and directly on the company bottom line result and its competitiveness in the long run. In a supplychain, an organization will link to its suppliers upstream and to its distributors downstream in order to serve its customers. Usually, materials, information, capital, labour, technology, financial assets and other resources flow through the supply-chain. Since the goal of the firm is to maximize profits, the firm must maximize benefits and minimize costs along the supply-chain. The firm must weigh the benefits versus the cost of each decision it makes along its supply-chain (Mathew \& Mee, 2018). 
International Journal of Supply Chain and Logistics

ISSN 2520-3983 (Online)

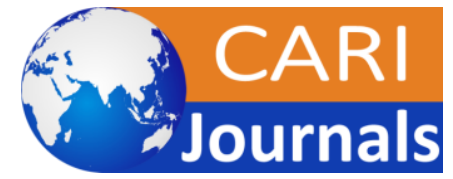

Vol. 5, Issue No.1, pp 46 - 66, 2021

www.carijournals.org

\subsection{Problem Statement}

Changes in the business environment have forced $80 \%$ of large-scale enterprises to realign their freight forwarding activities, and also to flatten their hierarchies, a short-term strategy, in order to speed up information flows (CCG, 2010). Moreover, in order to cut costs, freight forwarding companies use logistics optimization to streamline operations, this is a long-term strategy (KNBS, 2010). Currently, companies outsource $90 \%$ of their logistics processes (OECD, 2012). All these strategies have been necessitated by big losses, impropriety, and gross logistics mismanagement which are hampering improved and sustained performance of freight forwarding companies. Most freight forwarding companies in Kenya operate at a technical efficiency of about 59\% compared to their counterparts in South Africa at $70 \%$ and Malaysia at about $74 \%$ hence logistics optimization may help to close this gap. According to a report by Deloitte (2012) on freight forwarding companies in Kenya, logistics optimization saved various firms over Kshs.70 Billion in the financial year (FY) 2011/2012. According to another survey by KIFWA of 2011, 2012 and 2013 on the life span of freight forwarding firms, the firms were winding up at notable percentage indices, fluctuating between $49 \%, 54 \%$ and $58 \%$ respectively; poor logistics management was cited as the main reason.

The freight forwarding industry has always accounted for $30 \%$ of the country's Gross Domestic Product (GDP), provided employment to about 2.6 million people in the formal and informal sectors of the economy, however they have been experiencing problems in the performance of their operations management (USAID, 2012). In view of the foregoing, it is relevant to investigate how Kenyan organizations could have logistics management in the most efficient manner with regard to customer service and cost (ISO, 2010). In Kenya, studies have reported mixed findings with regard to logistics management, for instance, a study by Mathenge and Dihel (2011) on the role of clearing and forwarding agents in reforming East Africa community logistics management sector found that firms in Kenya are faced with challenges of measuring the performance of their logistics models because they are not able to anticipate the requirements for clearing and removing the cargo from the port.

A study by Ngonela, Mwaniki and Namusonge (2014), on drivers of logistics management on tea processing firms in Bomet County found out that optimal logistics management reduces costs, reduce risks and gain competitive advantage. While much research has focused on the problems facing logistics management generally in organizations in Kenya, not much research has been done to study logistics optimization and its influence on performance of freight forwarding companies in Kenya. It is against this backdrop; the present study sets out to investigate the influence of logistics optimization on performance of freight forwarding companies in Kenya. 
International Journal of Supply Chain and Logistics

ISSN 2520-3983 (Online)

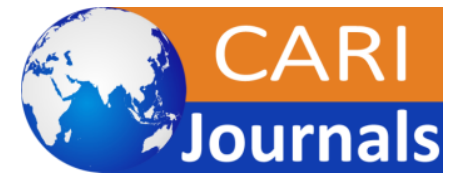

Vol. 5, Issue No.1, pp 46 - 66, 2021

www.carijournals.org

\subsection{Objectives of the Study}

i. To find out the influence of logistics information system on performance of freight forwarding companies in Kenya.

ii. To establish the influence of freight management on performance of freight forwarding companies in Kenya.

iii. To determine the influence of distributor base rationalization on performance of freight forwarding companies in Kenya.

iv. To explore the influence of transport planning on performance of freight forwarding companies in Kenya.

\subsection{LITERATURE REVIEW}

\subsection{The Logistics Theory}

Mentzer (1988) was the proponent of the logistics theory. He defined the term logistics as the set of activities including planning, organization and controlling of the material flow, from the point of extraction (raw material) until consumption of the finished product and reverse flows of the manufactured goods, with the objective of satisfying the customer's and stakeholders' needs and interests: to provide a good customer service, at low cost, low tied-up capital and minimal negative environmental impact (David \& Robert, 2013). In the oil sector, logistics is also characterized activities that relate to delivering the right product or service in the right quantity and quality, at the right place and right time, to the right customer whilst maintaining the right cost.

\subsection{Logistics Optimization}

\subsubsection{Logistics Information System}

In achieving performance, logistics information system comes in handy. According to Chang, Chiang and Pai (2012) logistics information system was defined as the flow of data in different directions with variable contents between various data base (department) within a company. Before, the logistics information system within the logistics had become vital since it enabled chains to respond on real time and accurate data (Bumstead \& Cannons, 2012). Firms then, looked at logistics information system as an asset, since it was not possible to have efficient and reliable materials flow without it. Samson (2012) concurred that, the flow of accurate and real time information in logistics was considered very important to the flow of materials. This logistics information system explosion had enabled logistics to become an important weapon in the firm's arsenal to add value to the bottom line (Bowersox, Closs \& Cooper, 2010). Information sharing was a key to success of logistics performance. 


\subsubsection{Freight Management}

Freight management is the most important economic activity among the components of business logistics systems. Freight management makes goods and products movable and provides timely and regional efficacy to promote value-added under the least cost principle. Kenyon and Meixell (2011) opine that freight management involves the activities involved in shipping any goods or finished products from suppliers to a facility or to warehouses and sales locations.

\subsubsection{Distributor Base Rationalization}

Distributor base rationalization is a conscientious effort to determine the right number of distributors to do business with (Gabbard, 2014). The beginning point of the process is determining the optimal number of suppliers that a firm should maintain and then focusing on identifying which incumbent firms should remain in the supply base in a given commodity team or division (Amayi, 2011). The idea is to reduce purchases from marginal or poor performing distributors while increasing and concentrating purchases among their more desirable top-performing distributors (Kotabe, 2008).

\subsubsection{Transport Planning}

The transportation is infrastructure that means roads, seaports, airports, rail, and canal. All these exist along nodes and links of transportation network. The transportation and infrastructure focus on operational and policy issues within transportation and infrastructure areas that affect logistics operation (Reitner \& Wolfgang, 2012). 


\subsection{Operationalization of Variables}

\section{Logistics Information System}

- Database Design Management

- Inventory Management Systems

- Supply Production Management

\section{Freight Management}

- Tracking Systems

- Fuel Management Systems

- Fleet Scheduling

\section{Distributor Base Rationalization}

- Logistics Spend Visibility

- Sustainability

- Logistics Contracts

\section{Transport Planning}

- Master Blueprint

- Capacity Management

- Multimodal System

\section{Independent Variables}

Dependent Variable

Figure 1: Conceptual Framework

Source: (Author, 2020)

\subsection{METHODOLOGY}

Descriptive research design was adopted. The study preferred this method because it allows an indepth study of the subject. Data was collected from deputy heads and heads of procurement in 45 freight forwarding companies in Kenya, who are registered members of KIFWA according to its 2019 directory. Questionnaires were used to collect data. The questionnaires were tested for validity and reliability using $10 \%$ of the total sample respondents. Data was analyzed through descriptive statistical methods such as means, standard deviation, frequencies and percentage. Inferential analyses were used in relation to correlation analysis and regression analysis to test the relationship between the four explanatory variables and the explained variable. Multiple regression models were used to show the relationship between the predicted variable and the predictor variables. 
International Journal of Supply Chain and Logistics

ISSN 2520-3983 (Online)

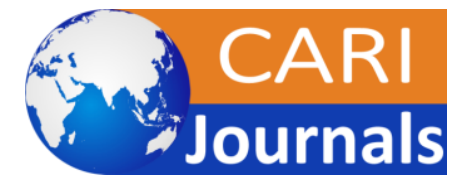

Vol. 5, Issue No.1, pp 46 - 66, 2021

www.carijournals.org

$$
Y=\beta_{0}+\beta_{1} X_{1}+\beta_{2} X_{2}+\beta_{3} X_{3}+\varepsilon
$$

Where:

$\mathrm{Y}=$ Performance of Freight Forwarding Companies in Kenya

$\alpha$ is the y-intercept or model coefficient;

$\beta_{1}-\beta_{4}=$ the coefficients of the independent variables;

$\mathrm{X}_{1}=$ Logistics Information System

$\mathrm{X}_{2}=$ Freight Management

$\mathrm{X}_{3}=$ Distributor Base Rationalization

$\mathrm{X}_{4}=$ Transport Planning

$\varepsilon$ is the error term

\subsection{RESULTS FINDINGS}

\subsection{Descriptive Statistics}

\subsubsection{Logistics Information System}

The first objective of the study was to investigate the influence of logistics information system on performance of freight forwarding companies in Kenya. The respondents were asked to indicate to what extent did logistics information system influence performance of freight forwarding companies in Kenya. Results indicated that majority of the respondents $37 \%$ agreed that it was to a very great extent, $33 \%$ said that it was to a great extent, $19 \%$ said it was moderate, while little extent and not all were at 4 and $7 \%$ respectively.

\section{Logistics Information System}

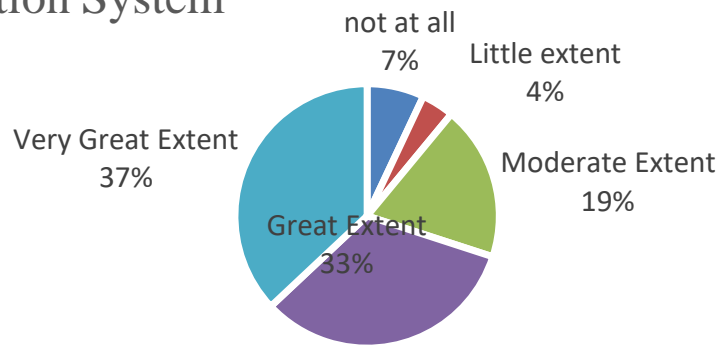

\section{Figure 2: Logistics Information System}

The responses were rated on a Likert scale and the results presented in Table 1 below and was rated on a 5-point Likert scale ranging from; $1=$ strongly disagree to $5=$ strongly agree. The scores of 'strongly disagree' and 'disagree' have been taken to represent a statement not agreed upon, equivalent to mean score of 0 to 2.5. The score of 'neutral' has been taken to represent a statement agreed upon, equivalent to a mean score of 2.6 to 3.4. The score of 'agree' and 'strongly agree' 
have been taken to represent a statement highly agreed upon equivalent to a mean score of 3.5 to 5.

Results indicated that majority of the respondents $77 \%$ agreed on statement that database design management plays a significant role in timely deliveries. Results indicated that majority of the respondents $60 \%$ agreed on statement that inventory management systems play a significant role in timely deliveries. Further results indicated that $63 \%$ of the respondents were in agreement that supply production management plays a significant role in timely deliveries. Results also indicated that $60 \%$ of the respondents agreed that database design management plays a significant role in cost reduction. Results also indicated that $54 \%$ of the respondents agreed that inventory management systems play a significant role in cost reduction. Further results indicated that $49 \%$ of the respondents were in agreement that supply production management plays a significant role in cost reduction.

Results also indicated that $61 \%$ of the respondents agreed that database design management plays a significant role in improving turnaround time. Results also indicated that $76 \%$ of the respondents agreed that inventory management systems play a significant role in improving turnaround time. Results also indicated that $58 \%$ of the respondents agreed that supply production management plays a significant role in improving turnaround time. The average mean of the respondents was 3.68 indicating that majority of the respondents agreed with influence of logistics information system on performance of freight forwarding companies in Kenya. However, the responses were varied as shown by a standard deviation of 0.88 . These findings indicate that through logistics information system, the management of freight forwarding companies service could improve their performance. This agrees with a study done by Christopher (2008) that organizations must look toward their continuous logistics information system improvements. The opportunities for cost savings and processes improvements can be enormous as the impact on margins is considerable. 
International Journal of Supply Chain and Logistics

ISSN 2520-3983 (Online)

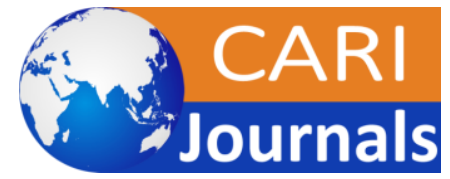

Vol. 5, Issue No.1, pp 46 - 66, 2021

www.carijournals.org

Table 1: Logistics Information System Influence on Performance of Freight Forwarding Companies

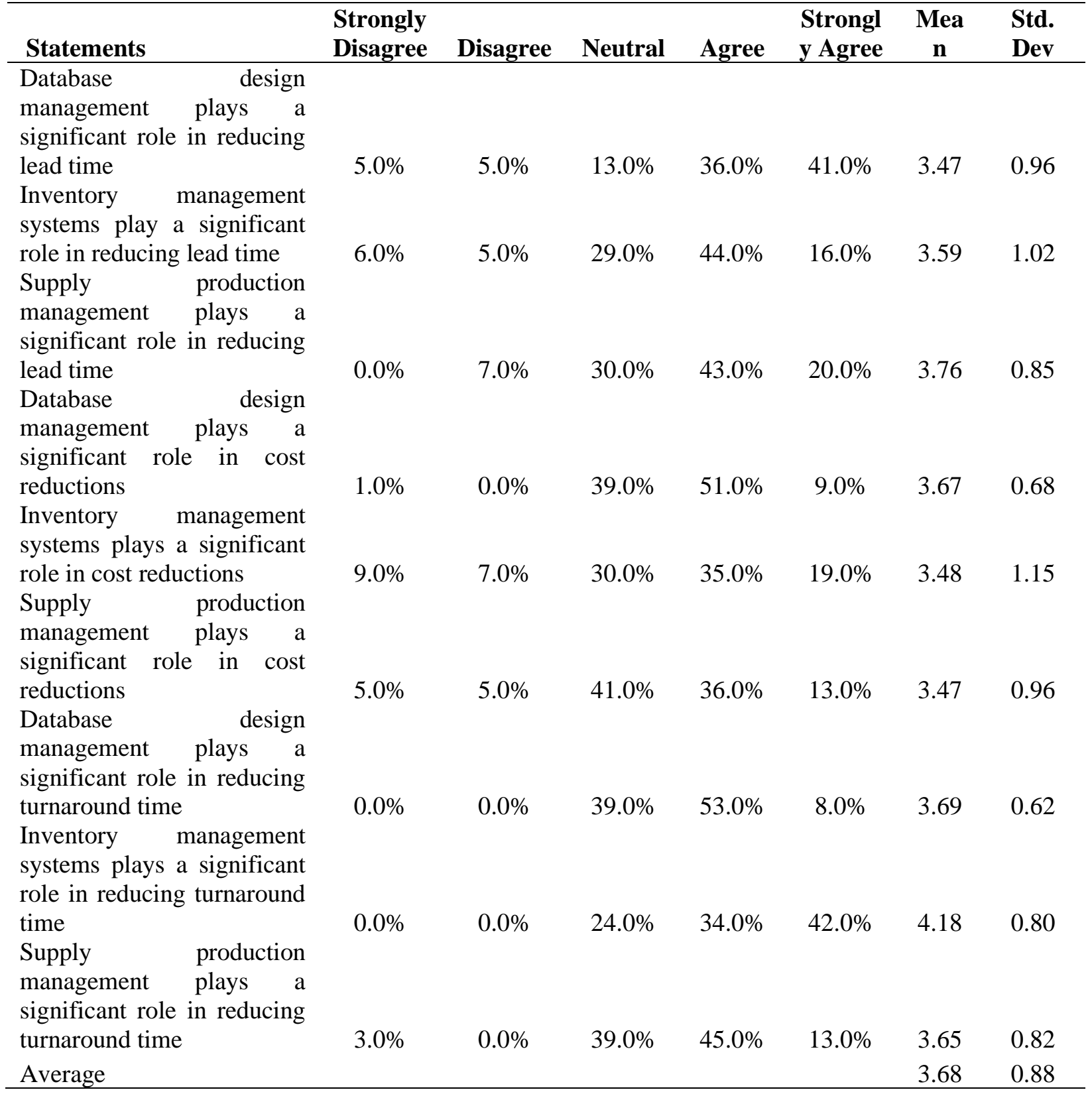

\subsubsection{Freight management}

There was also need to establish how freight management influenced performance of freight forwarding companies in Kenya as the second objective. The respondents were asked to comment on extent of freight management influence performance of freight forwarding companies in Kenya. Results also showed that majority of the respondents indicated $49 \%$ was very great extent, $44 \%$ 
International Journal of Supply Chain and Logistics

ISSN 2520-3983 (Online)

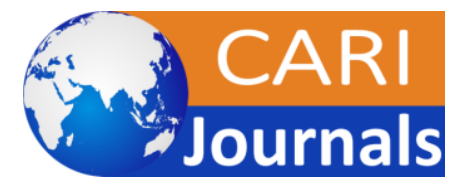

Vol. 5, Issue No.1, pp 46 - 66, 2021

www.carijournals.org

great extent, not at all was $2 \%$ while little extent and moderate extent was $3 \%$ while little extent was at $2 \%$.

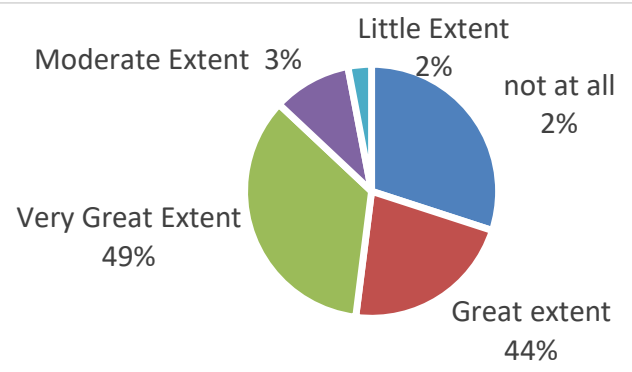

Figure 3: Freight Management

Results indicated that majority of the respondents $100 \%$ agreed on the statement that tracking systems plays a significant role in timely deliveries. Results indicated that majority of the respondents $64 \%$ agreed on the statement that fuel management systems play a significant role in timely deliveries. Results indicated that majority of the respondents $47 \%$ agreed on the statement fleet scheduling plays a significant role in timely deliveries. Results indicated that majority of the respondents $100 \%$ agreed on the statement that tracking systems play a significant role in cost reduction. Results indicated that majority of the respondents $97 \%$ agreed on the statement that fuel management systems play a significant role in cost reduction. Results indicated that majority of the respondents $93 \%$ agreed on the statement that fleet scheduling plays a significant role in cost reduction.

Results indicated that majority of the respondents $91 \%$ agreed on the statement that tracking systems plays a significant role in improving turnaround time. Results indicated that majority of the respondents $90 \%$ agreed on the statement that fuel management systems play a significant role in improving turnaround time. Results indicated that majority of the respondents $89 \%$ agreed on the statement that fleet scheduling plays a significant role in improving turnaround time. The average mean of the respondents was 4.16 indicating that majority of the respondents agreed with influence of freight management on performance of freight forwarding companies in Kenya. However, the responses were varied as shown by a standard deviation of 0.83 . The results imply that freight forwarding companies greatly benefit when freight management is embraced to reduce costs, introduce durability indices and performance ratings (Ackali, 2009). 
International Journal of Supply Chain and Logistics

ISSN 2520-3983 (Online)

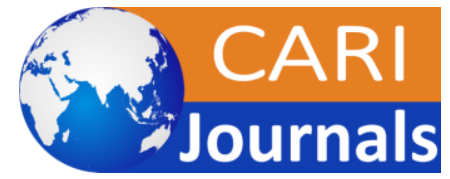

Vol. 5, Issue No.1, pp 46 - 66, 2021

www.carijournals.org

Table 2: Freight Management Influence on Performance of Freight Forwarding Companies

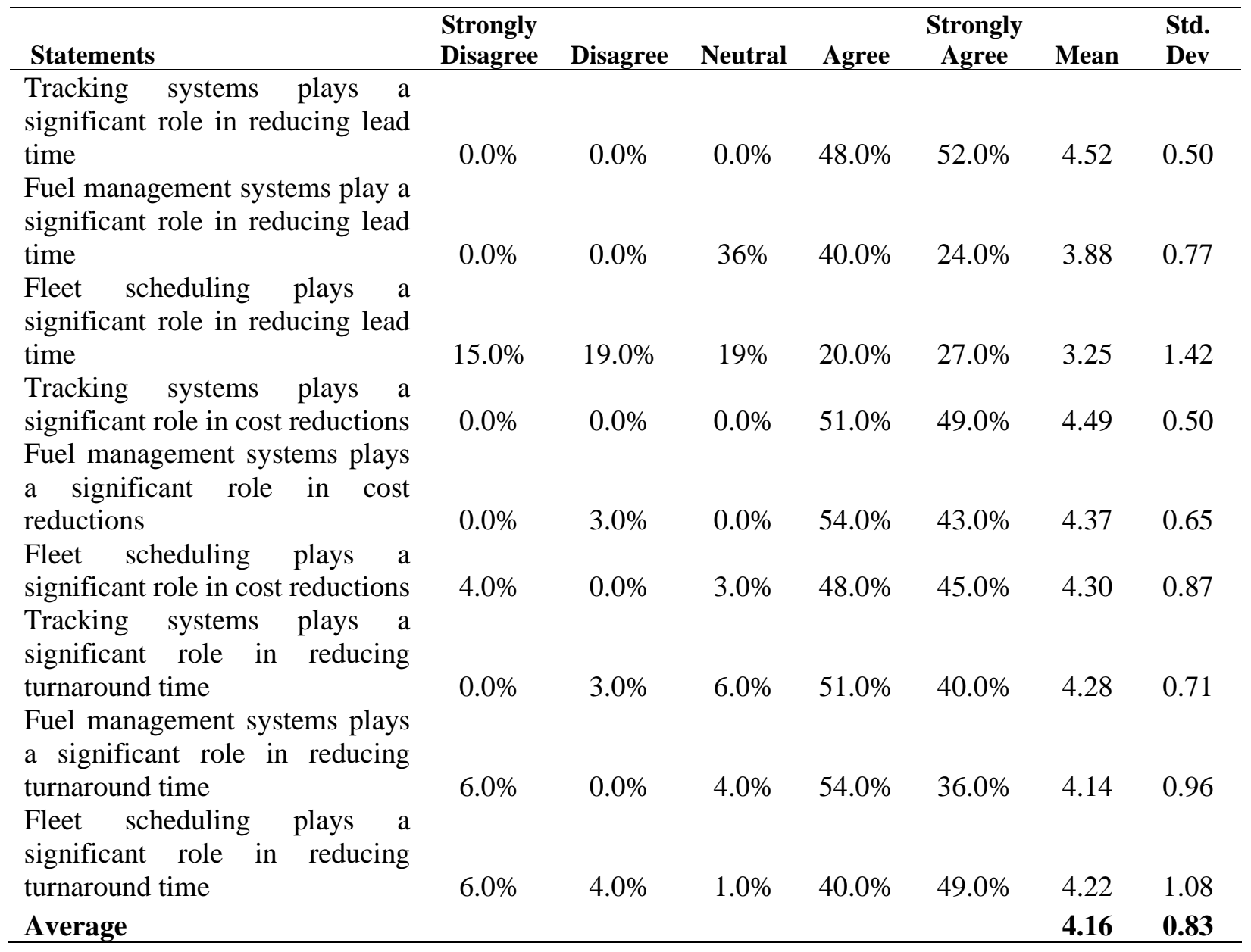

\subsubsection{Distributor Base Rationalization}

There was also need to establish how distributor base rationalization influenced performance of freight forwarding companies in Kenya as the third objective. The respondents were asked to comment on extent of distributor base rationalization influence on performance of freight forwarding companies in Kenya. Results indicated that majority of the respondents $48 \%$ agreed that it was to a very great extent, $45 \%$ said that it was to a great extent, $2 \%$ said it was moderate; little extent was $2 \%$ and not all at $3 \%$. 
International Journal of Supply Chain and Logistics

ISSN 2520-3983 (Online)

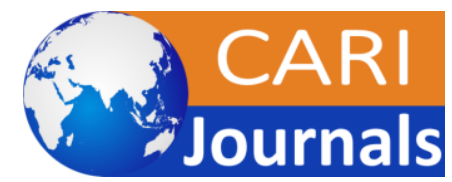

Vol. 5, Issue No.1, pp 46 - 66, 2021

www.carijournals.org

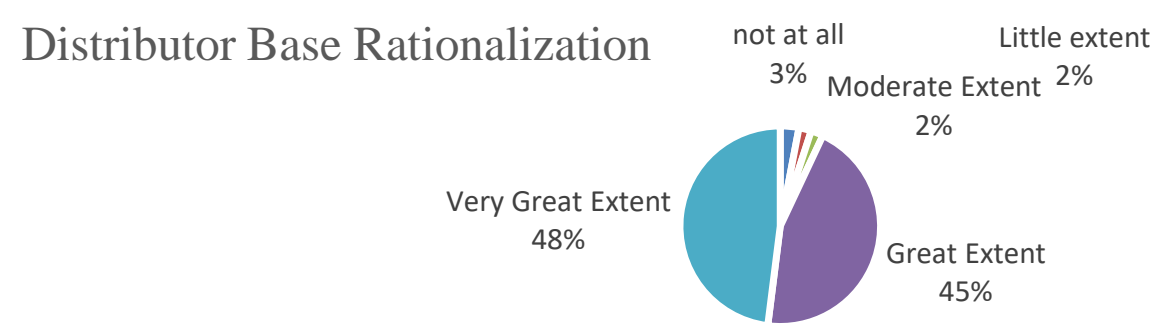

\section{Figure 4: Distributor Base Rationalization}

Results indicated that majority of the respondents $70 \%$ agreed on the statement that logistics spend visibility plays a significant role in timely deliveries. Results also indicated that majority of the respondents $94 \%$ agreed on the statement that sustainability plays a significant role in timely deliveries. Results also indicated that majority of the respondents $53 \%$ agreed on the statement that logistics contracts play a significant role in timely deliveries.

Results also indicated that majority of the respondents $50 \%$ agreed on the statement that logistics spend visibility plays a significant role in cost reduction. Results also indicated that majority of the respondents $80 \%$ agreed on the statement that sustainability play a significant role in cost reduction. Results also indicated that majority of the respondents $61 \%$ agreed on the statement that logistics contracts play a significant role in cost reduction.

Results also indicated that majority of the respondents $67 \%$ agreed on the statement that logistics spend visibility plays a significant role in improving turnaround time. Results also indicated that majority of the respondents $59 \%$ agreed on the statement that sustainability plays a significant role in improving turnaround time. Results also indicated that majority of the respondents $66 \%$ agreed on the statement that logistics contracts play a significant role in improving turnaround time.

The average mean of the respondents was 3.93 indicating that majority of the respondents agreed with influence of distributor base rationalization on performance of freight forwarding companies in Kenya. However, the responses were varied as shown by a standard deviation of 0.93 . These findings imply that through distributor base rationalization, freight forwarding companies can improve the value gained from distributor base rationalization (Arthur, 2009). 
International Journal of Supply Chain and Logistics

ISSN 2520-3983 (Online)

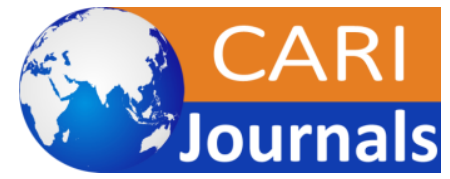

Vol. 5, Issue No.1, pp 46 - 66, 2021

www.carijournals.org

Table 3: Distributor Base Rationalization Influence on Performance of Freight Forwarding Companies

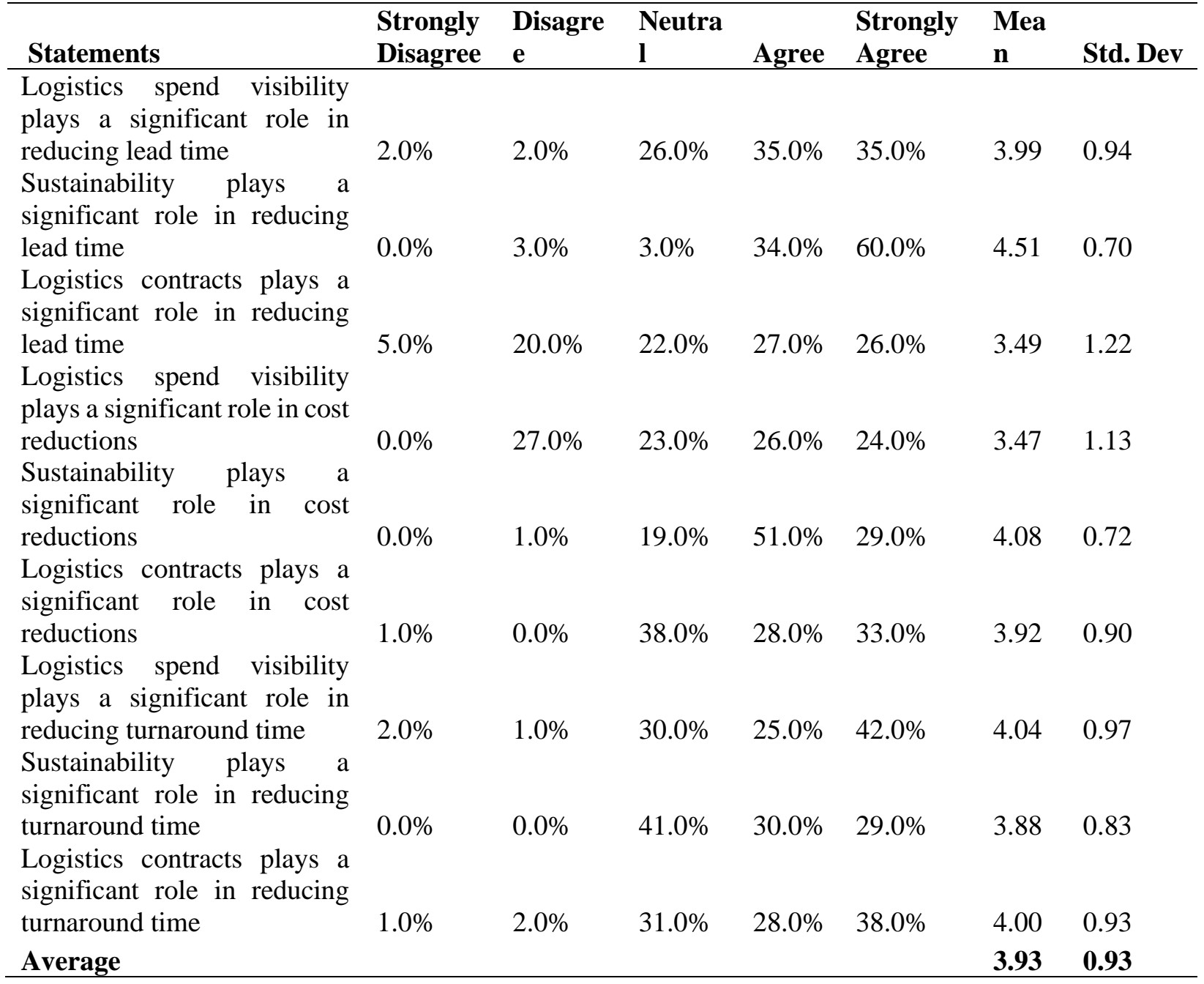

\subsubsection{Transport Planning}

The last objective of the study was to assess the influence of transport planning on performance of freight forwarding companies in Kenya. The respondents were asked to indicate to what extent transport planning influenced performance of freight forwarding companies in Kenya. Results indicated that majority of the respondents $19 \%$ agreed that it was to a very great extent, $33 \%$ said that it was to a great extent, $30 \%$ said it was moderate, while little extent was $11 \%$ and not all was at $7 \%$ respectively. 
International Journal of Supply Chain and Logistics

ISSN 2520-3983 (Online)

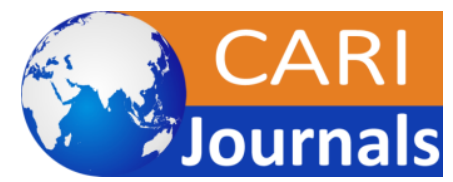

Vol. 5, Issue No.1, pp 46 - 66, 2021

www.carijournals.org

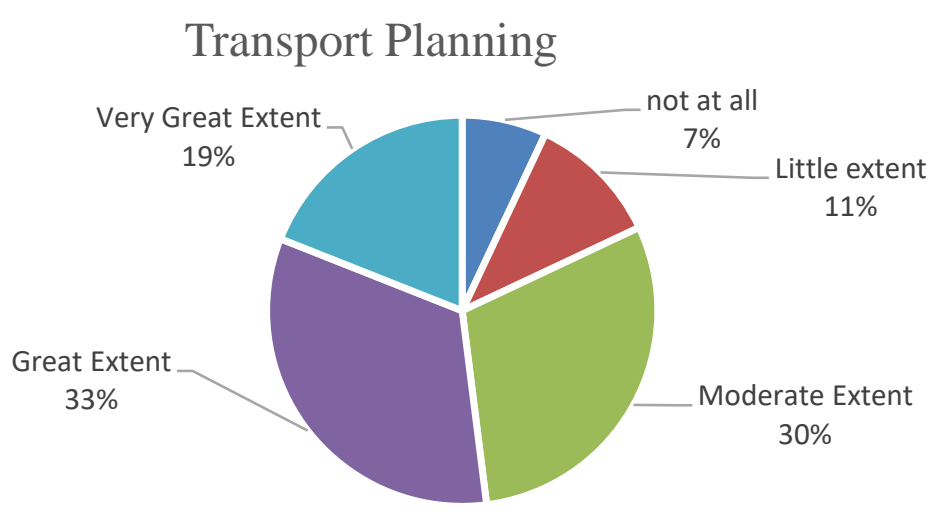

\section{Figure 4: Transport Planning}

The respondents were also asked to comment on statements regarding transport planning influence on performance of freight forwarding companies in Kenya. Results indicated that majority of the respondents $86 \%$ agreed on the statement that master blueprint plays a significant role in timely deliveries. Results also indicated that $90 \%$ of the respondents were in agreement that capacity management plays a significant role in timely deliveries. Results indicated that majority of the respondents $100 \%$ agreed on the statement that multimodal system plays a significant role in timely deliveries.

Results indicated that majority of the respondents $90 \%$ agreed on the statement that master blueprint plays a significant role in cost reduction. Results indicated that majority of the respondents $96 \%$ agreed on the statement that capacity management plays a significant role in cost reduction. Results indicated that majority of the respondents $95 \%$ agreed on the statement that multimodal system plays a significant role in cost reduction.

Results indicated that majority of the respondents $92 \%$ agreed on the statement that master blueprint plays a significant role in improving turnaround time. Results indicated that majority of the respondents $91 \%$ agreed on the statement that capacity management plays a significant role in improving turnaround time. Results indicated that majority of the respondents $85 \%$ agreed on the statement that multimodal system plays a significant role in improving turnaround time.

The average mean of the respondents was 4.27 indicating that majority of the respondents agreed with statements regarding transport planning influence on performance of freight forwarding companies in Kenya. However, the responses were varied as shown by a standard deviation of 0.86. These findings imply that transport planning was an important aspect in the freight forwarding companies. The findings agree with David (2014) that using transport planning when managing supply chains can save an organization a lot of unnecessary costs 
International Journal of Supply Chain and Logistics

ISSN 2520-3983 (Online)

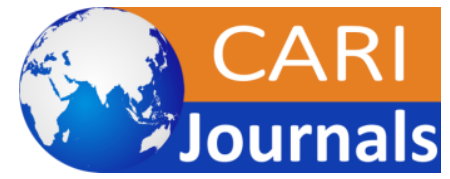

Vol. 5, Issue No.1, pp 46 - 66, 2021

www.carijournals.org

Table 4: Transport Planning Influence on Performance of Freight Forwarding Companies

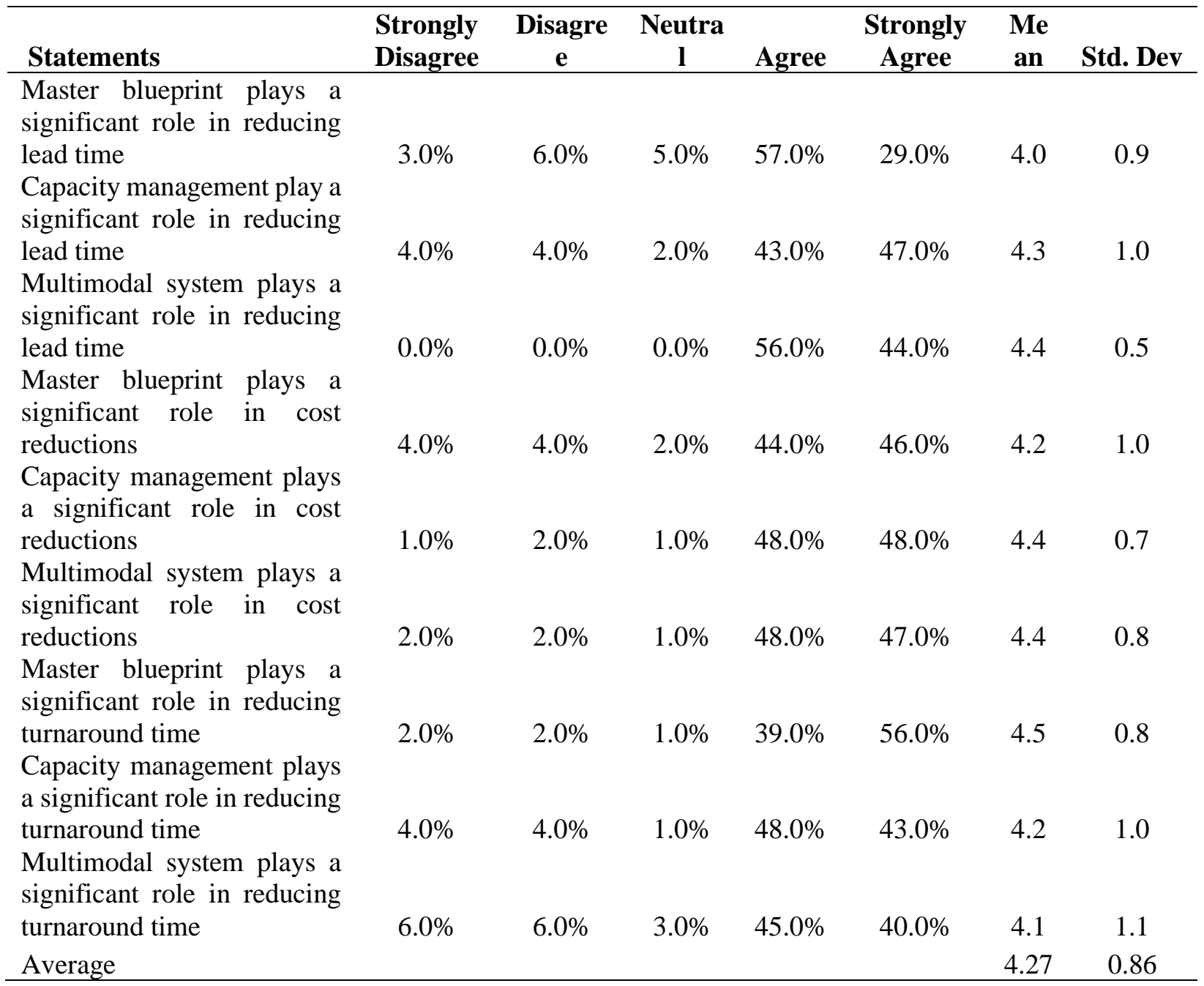




\subsection{Correlation Analysis}

Correlation analysis was used to determine both the significance and degree of association of the variables and also predict the level of variation in the dependent variable caused by the independent variables. The correlation technique is used to analyze the degree of association between two variables. The results of the correlation analysis are summarized in Table 4.

Table 4: Summary of Pearson's Correlations

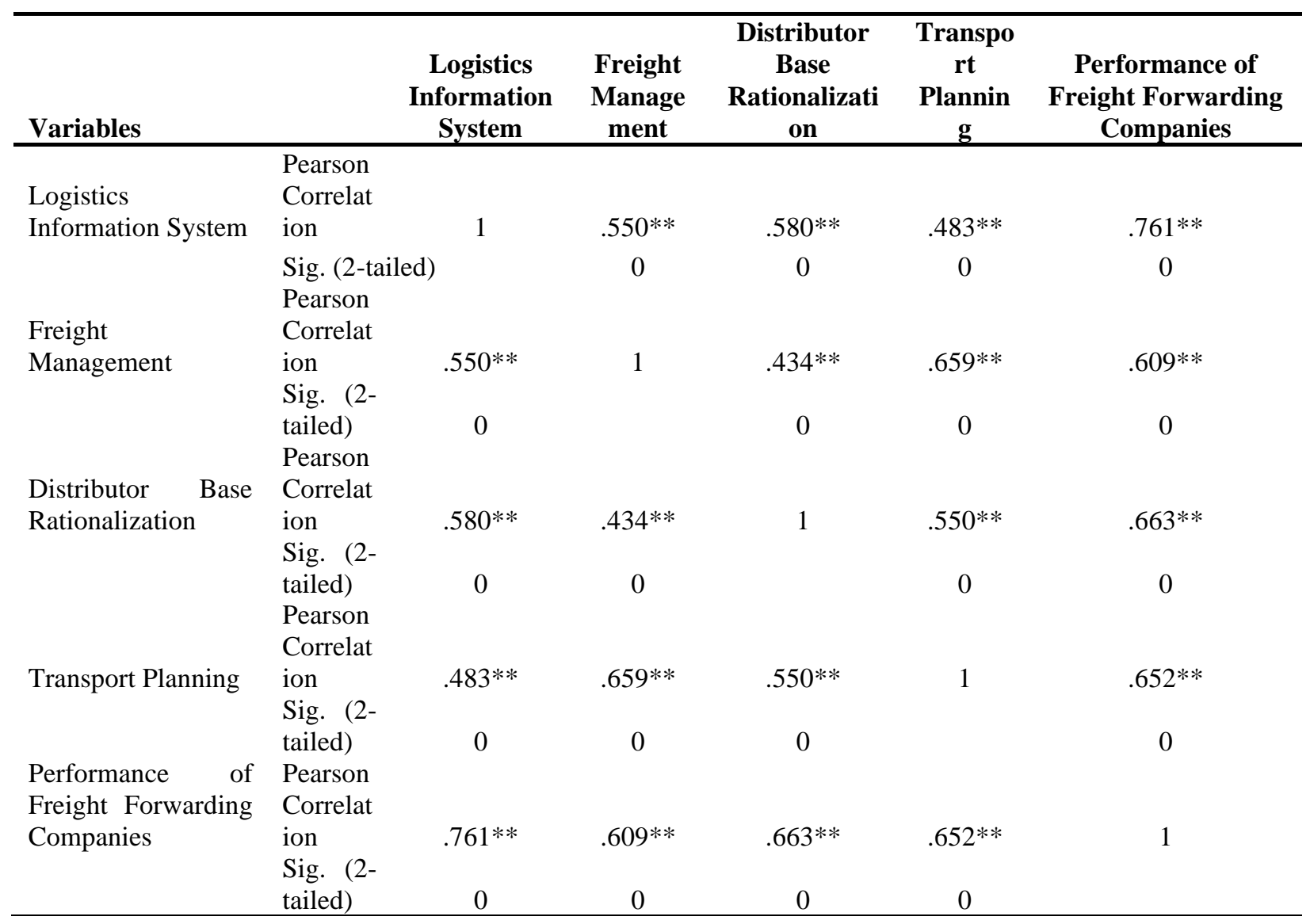

** Correlation is significant at the 0.01 level (2-tailed).

The correlation summary shown in Table 5 indicates that the associations between each of the independent variables and the dependent variable were all significant at the $95 \%$ confidence level. The correlation analysis to determine the relationship of logistics optimization on performance of freight forwarding companies in Kenya, Pearson Correlation coefficient computed and tested at $5 \%$ significance level.

The results indicate that there is a positive relationship $(r=0.761)$ between logistics information system and performance of freight forwarding companies. In addition, the researcher found the relationship to be statistically significant at $5 \%$ level $(\mathrm{p}=0.000,<0.05)$. The correlation analysis to determine the relationship between logistics information system and performance of freight 
International Journal of Supply Chain and Logistics

ISSN 2520-3983 (Online)

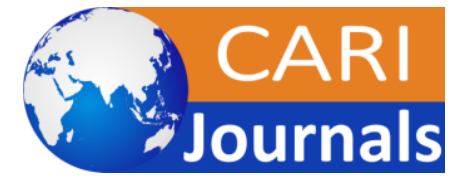

Vol. 5, Issue No.1, pp 46 - 66, 2021

www.carijournals.org

forwarding companies, Pearson Correlation coefficient computed and tested at 5\% significance level.

The correlation analysis to determine the relationship between freight management and performance of freight forwarding companies, Pearson Correlation coefficient computed and tested at $5 \%$ significance level. The results indicate that there is a positive relationship $(\mathrm{r}=0.609)$ between freight management and performance of freight forwarding companies. In addition, the researcher found the relationship to be statistically significant at $5 \%$ level $(p=0.000,<0.05)$.

The correlation analysis to determine the relationship between distributor base rationalization and performance of freight forwarding companies, Pearson Correlation coefficient computed and tested at 5\% significance level. The results indicate that there is a positive relationship $(\mathrm{r}=0.663)$ distributor base rationalization and performance of freight forwarding companies. In addition, the researcher found the relationship to be statistically significant at $5 \%$ level $(p=0.000,<0.05)$.

The correlation analysis to determine the relationship between transport planning and performance of freight forwarding companies, Pearson Correlation coefficient computed and tested at 5\% significance level. The results indicate that there is a positive relationship $(r=0.652)$ between transport planning and performance of freight forwarding companies. In addition, the researcher found the relationship to be statistically significant at $5 \%$ level $(\mathrm{p}=0.000,<0.05)$. Hence, it is evident that all the independent variables could explain the changes in the performance of freight forwarding companies on the basis of the correlation analysis.

\subsection{Regression Analysis}

In this study multivariate regression analysis was used to determine the significance of the relationship between the dependent variable and all the independent variables pooled together. Regression analysis was conducted to find the proportion in the dependent variable (performance of freight forwarding companies) which can be predicted from the independent variables (logistics information system, freight management, distributor base rationalization and transport planning). The results of regression analysis revealed there is a significant positive relationship between dependent variable (performance of freight forwarding companies and the independent variables (logistics information system, freight management, distributor base rationalization and transport planning).

The independent variables reported $\mathrm{R}$ value of 0.846 indicating that there is perfect relationship between dependent variable and independent variables. $\mathrm{R}$ square value of 0.716 which means that $71.6 \%$ of the corresponding variation in performance of the freight forwarding companies can be explained or predicted by (logistics information system, freight management, distributor base rationalization and transport planning) which indicated that the model fitted the study data. The results of regression analysis revealed that there was a significant positive relationship between dependent variable and independent variable at $(\beta=1.240), \mathrm{p}=0.00<0.05)$. 
International Journal of Supply Chain and Logistics

ISSN 2520-3983 (Online)

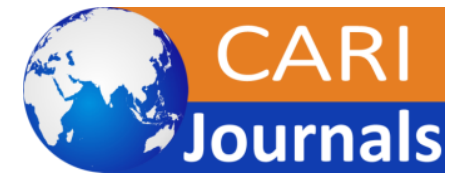

Vol. 5, Issue No.1, pp 46 - 66, 2021

www.carijournals.org

Table 5: Model Summary

\begin{tabular}{lllll}
\hline Model & R & R Square & Adjusted R Square & $\begin{array}{l}\text { Std. Error of the } \\
\text { Estimate }\end{array}$ \\
\hline 1 & $.846^{\mathrm{a}}$ & .716 & .704 & .149
\end{tabular}

Table 6: ANOVA

\begin{tabular}{llllllll}
\hline Model & & $\begin{array}{l}\text { Sum } \\
\text { Squares }\end{array}$ & of & df & $\begin{array}{l}\text { Mean } \\
\text { Square }\end{array}$ & F & Sig. \\
\hline 1 & Regression & 5.369 & 4 & 1.342 & 53.680 & $.000^{\mathrm{b}}$ \\
& Residual & 2.131 & 85 & 0.025 & & \\
& Total & 7.5 & 89 & & & \\
\hline
\end{tabular}

The significance value is 0.000 which is less than 0.05 thus the model is statistically significant in predicting how logistics information system, freight management, distributor base rationalization and transport planning influence performance of freight forwarding companies. The study therefore establishes that; logistics information system, freight management, distributor base rationalization and transport planning influence performance of freight forwarding companies. These results agree with Paul (2011) results which indicated a positive and significant influence of logistics optimization on performance of freight forwarding companies.

Table 7: Coefficients of Determination

\begin{tabular}{lccccc}
\hline & \multicolumn{2}{c}{$\begin{array}{c}\text { Unstandardized } \\
\text { Coefficients } \\
\text { Std. Error }\end{array}$} & $\begin{array}{c}\text { Standardized } \\
\text { Coefficients } \\
\text { Beta }\end{array}$ & t & Sig. \\
\hline $\begin{array}{l}\text { (Constant) } \\
\text { Logistics Information }\end{array}$ & 1.240 & 0.260 & & 4.771 & 0.000 \\
$\begin{array}{l}\text { System } \\
\text { Freight Management }\end{array}$ & 0.462 & 0.073 & 0.463 & 6.299 & 0.000 \\
Distributor Base & 0.108 & 0.035 & 0.243 & 3.075 & 0.000 \\
Rationalization & & & & & \\
Transport Planning & 0.071 & 0.023 & 0.218 & 3.008 & 0.000 \\
\hline
\end{tabular}

$$
Y=\beta_{0}+\beta_{1} X_{1}+\beta_{2} X_{2}+\beta_{3} X_{3}+\beta_{4} X_{4}+\varepsilon
$$

Where $\mathrm{Y}=$ Performance of Freight Forwarding Companies

$\beta_{0}=$ Constant

$\mathrm{X}_{1}=$ Logistics Information System

$\mathrm{X}_{2}=$ Freight Management

$\mathrm{X}_{3}=$ Distributor Base Rationalization

$\mathrm{X}_{4}=$ Transport Planning 
International Journal of Supply Chain and Logistics

ISSN 2520-3983 (Online)

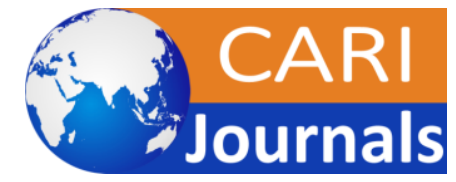

Vol. 5, Issue No.1, pp 46 - 66, 2021

www.carijournals.org

$\varepsilon=$ Error Term at $95 \%$ confidence level.

The regression equation will be;

$\mathrm{Y}=1.240+0.462 \mathrm{X}_{1}+0.108 \mathrm{X}_{2}+0.071 \mathrm{X}_{3}+0.064 \mathrm{X}_{4}$

The regression equation above has established that taking all factors into account (logistics information system, freight management, distributor base rationalization and transport planning) constant at zero, performance of freight forwarding companies will be an index of 1.240. The findings presented also shows that taking all other independent variables at zero, a unit increase in logistics information system will lead to a 0.462 increase in performance of freight forwarding companies. The P-value was 0.000 which is less than 0.05 and thus the relationship was significant.

The study also found that a unit increase in freight management will lead to a 0.108 increase in in performance of freight forwarding companies. The P-value was 0.000 and thus the relationship was significant. In addition, the study found that a unit increase in distributor base rationalization will lead to a 0.071 increase in the performance of freight forwarding companies. The P-value was 0.000 and thus the relationship was significant.

Lastly, the study found that a unit increase in transport planning will lead to a 0.064 increase in the performance of freight forwarding companies. The P-value was 0.021 and hence the relationship was significant since the p-value was lower than 0.05 . The findings of the study show that, logistics information system contributed most to performance of freight forwarding companies.

\subsection{SUMMARY, CONCLUSION AND RECOMMENDATIONS}

\subsection{Summary of the Findings}

The main aim of the study was to study the influence of logistics optimization on performance of freight forwarding companies in Kenya. It specifically sought to determine the influence of; logistics information system, freight management, distributor base rationalization and transport planning influence performance of freight forwarding companies. Correlation and regression results revealed that this was an important variable that could perhaps be explained by the observation from the findings that logistics information system was an important factor in influencing performance of freight forwarding companies.

Correlation and regression results revealed that this was an important variable that could perhaps be explained by the observation from the findings freight management was an important factor in influencing performance of freight forwarding companies. Correlation and regression results revealed that this was an important variable that could perhaps be explained by the observation from the findings that distributor base rationalization was an important factor in influencing performance of freight forwarding companies. Correlation and regression results revealed that this was an important variable that could perhaps be explained by the observation from the findings that transport planning was an important factor in influencing performance of freight forwarding companies. 
International Journal of Supply Chain and Logistics

ISSN 2520-3983 (Online)

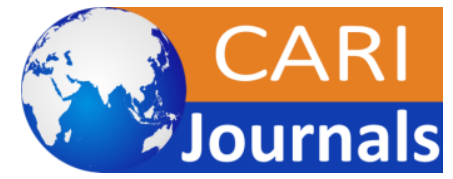

Vol. 5, Issue No.1, pp 46 - 66, 2021

www.carijournals.org

\subsection{Conclusion}

Based on the study findings, the study concludes that performance of freight forwarding companies can be improved by logistics information system, freight management, distributor base rationalization and transport planning.

\subsection{Recommendations}

To ensure that the freight forwarding companies have better performance they should focus more on using their logistics optimization that are vetted and with empirical backup so as to ascertain there is consistency of logistics. The study recommends that procurement officers should ensure that they strictly follow operational procedures to ensure that projects undertaken are of the right quality, in the right quantity, at the right time, to the right place from the right source. This will aim at satisfaction of customers in terms of cost, quality, and timeliness of the delivered product or service, minimizing administrative operating costs.

\section{REFERENCES}

Abrahamsson, M. (2008). The role of Logistics in Corporate Strategy. Business Process Management Journal, 10(2), 54-68.

Baiman, S., \& Rajan, M. (2012). Incentive issues in inter-firm relationships. International Journal of Accounting Organizations 27(2), 213-238.

Bask, A. H. (2011). Relationships among TPL providers and members of supply chains- a strategic perspective. The Journal of Business and Industrial Marketing, 16(6), 470-486.

Bauknight, D., \& Miller, R. J., (2015). Re-engineering Global Supply Chain. International Journal of Physical Distribution \& Logistics Management 30 (1), 13-34.

Bolumole, Y. (2011). The Supply Chain Role of Third-Party Logistics Providers. International Journal of Logistics Management, 12(2), 87-102.

Bourlakis, C. \& Bourlakis, M. (2015). Information technology safeguards, logistics asset specificity and fourth-party logistics network creation in the food retail chain, The Journal of Business \& Industrial Marketing, 20 (2), 88-99.

Bowersox, J., Closs, J., \& Cooper, M. (2010). Supply Chain Logistics Management (3rd Ed); Boston, Mass: McGraw-Hill.

Bumstead, J. \& Cannons, K. (2012). From 4PL to managed supply-chain operations, Logistics \& Transport Focus, 4(4), 18-24

Buyukozkan, G., Feyzioglu, O. \& Ersoy, M. (2015). Evaluation of 4PL operating models: A decision making approach based on 2-additive integral, International Journal of Production Economics, 121 (5), 112-120.

CCG. (2010). National Development Fund Report Instructional Structures and Reforms. Nairobi: Centre for Corporate Governance. 
International Journal of Supply Chain and Logistics

ISSN 2520-3983 (Online)

Vol. 5, Issue No.1, pp 46 - 66, 2021

www.carijournals.org

Chang, W., Chiang, M., \& Pai, Y. (2012). Cooperative Strategy in Supply Chain Networks. International Journal of Industrial Marketing Management 12 (1), 11-19.

Chang, Y.H. (2011). Logistical Management. Hwa-Tai Bookstore Ltd., Taiwan

Chopra, S., \& Meindl, P. (2013). Supply Chain Management: Strategy, Planning, \& Operation. (3th ed) NJ: Prentice-Hall. Inc

Dunn, S. D. (2010). Statistics and Data analysis for the Behavioural Science: Mc Graw Hill

Eisenhardt, M., \& Martin, J. A. (2010). Dynamic capabilities: what are they? Strategic Management Journal, 21(10/11), 1105-1121.

Fabbe-Costes, N., Jahre, M. \& Roussat, C. (2014). Supply chain integration: the role of logistics service providers, International Journal of Productivity and Performance Management, 58(1), 71- 91.

Kenyon, G. \& Meixell, M. (2011). Success factors and cost management strategies for logistics outsourcing. Journal of Management and Marketing Research, 8(7), 1-17

Kersten, W., Bemeleit, B., \& Blecker, T., (2016). "Managing Risks in Supply Chains: How to Build Reliable Collaboration in Logistics”, Published by Eric Schmidt, 5(8), 67-105

Ketokivi, M., \& Schroeder, R. (2014). Freight forwarding practices, strategic fit and performance: a routine-based view. International Journal of Operations \& Production Management, 24(1/2), 171-191.

Kwai-Sang, Tammala, V., Leung, J. \& Tang, X. (2014). A study on supply chain management practices: The Hong Kong freight forwarding perspective. International Journal of Physical Distribution and Logistics Management, 34 (6), 505-524

Laarhoven, V., Berglund, M., \& Peters, M. (2010). Third-party logistics in Europe five years later. International Journal of Physical Distribution \& Logistics Management 30(5), 425- 442

Lai, H., Ngai, T., \& Cheng, E. (2012). Measures for evaluating performance in transport logistics: International Journal of Transportation Research 3(8), 439-56

Lau, H. \& Goh, Y. (2014). An intelligent brokering system to support multi-agent web-based 4thparty logistics, In Proceedings of the 14th IEEE international conference on tools with artificial intelligence, 30(5), 154-161

Lieb, R., \& Butner, K. (2013). The North American Third-Party Logistics Industry in 2016: The

Ljungberg, D., \& Gebresenbet, G. (2014). Mapping out the potential for coordinated goods distribution in city centres: The case of Uppsala International Journal of Transport Management 8(3), 161-172.

Mars Group Kenya (2011). Freight forwarding and industry sector report. Retrieved from: Aid Effectiveness/Documents/Preparation of GoK sector plans/Draft Sector Plan-Freight forwarding \& Industry. 